\title{
Seasonality of ER Admissions in Northwestern Pennsylvania: A Cross-Sectional Study
}

\author{
Thais Rafael Guimaraes, Rebecca Smullin Dawson* \\ Allegheny College, Meadville, PA, USA \\ Email: "rdawson@allegheny.edu
}

Received 18 May 2016; accepted 21 June 2016; published 24 June 2016

Copyright (C) 2016 by authors and Scientific Research Publishing Inc.

This work is licensed under the Creative Commons Attribution International License (CC BY). http://creativecommons.org/licenses/by/4.0/

(c) (i) Open Access

\section{Abstract}

Seasonality, in the context of emergency room (ER) admissions, can be described as the periodic incidence of disease, corresponding to seasons, or other pre-established calendar periods. Respiratory diseases, in general, show a seasonal pattern with incidence peak at the winter season, however research still presents a considerable amount of inconsistency. Incidence of cardiovascular diseases (CVD) is also very well linked to the cold season. Gastrointestinal, genitourinary and neurological diseases are poorly studied in regards their seasonal patterns. This study aimed to assess seasonality of the five categories of diseases-respiratory, cardiovascular, gastrointestinal, genitourinary, and neurological-using data from a community hospital in northwestern PA. We analyzed 14 years (2000-2014) of data from the Meadville Medical Center (MMC) ER admissions. For each ER admission case, we had information about ICD-9 code, sex, insurance, race, age and date, time and year of admission. Statistical analyses were performed using SAS 9.4 University version software. We found significantly fewer cases of respiratory diseases in spring $(0 R=0.757)$, summer $(O R=0.579)$, and fall $(O R=0.741)$, when comparing to the winter season; however, seasonal differences were not found for cardiovascular, genitourinary, and neurological diseases. The implications of these results will primarily be used to improve Meadville's public health policies for cold seasons, and more specifically, implement programs that prepare the ER to receive and treat respiratory cases more efficiently in the cold season.

\section{Keywords}

Seasonality, Emergency Room, Meadville, Respiratory Diseases, Winter

\section{Introduction}

Seasonality is a cyclic change in disease occurrence over the course of a year [1] [2]. When focusing on emer${ }^{*}$ Corresponding author. 
gency room (ER) admissions, seasonality can be described as the periodic incidence of disease, corresponding to season, or another pre-established calendar period [3] [4]. For the purpose of this study, the seasonality of ER admissions for five major categories of diseases-cardiovascular, gastrointestinal, genitourinary, neurological and respiratory-was assessed.

Respiratory diseases, especially in Western societies, have been shown to have a winter peak of mortality and ER admissions [5]-[7]. Generally, this can be explained by a combination of environmental factors seen during the winter season. More specifically, when talking about infectious respiratory diseases, the causes can be related to prolonged survival of the pathogen in the environment [3], changes in the mucociliary function due to environmental factors, such as dry air and low temperatures [8] [9], and even changes in air pollution [10]-[12]. Although there is evidence of winter prevalence of respiratory diseases, the role of environmental factors and risk for these diseases still controversial [9] [13]-[15]. Some research shows that different respiratory diseases can have a distinct and particular seasonal pattern [4].

There is a considerable amount of evidence in the literature supporting that cardiovascular diseases (CVD) show higher rates of incidence during winter [16]-[23]. The higher incidence is seen not only in cardiac death [24] [25], but also in overall ER admissions [26]. The reason this is so well documented may be the fact that winter environmental conditions have already been closely related to CVD. In cold temperature people show more sympathetic activation (compensatory vasoconstriction mechanism) and higher sodium intake, both lead to an increase in blood pressure and heart rate [21] [27] [28]. Other behavioral factors related to the cold season, such as social withdrawal, high-fat diet consumption, and decreased physical activity, can also contribute to the seasonality of CVD [29].

Research of gastrointestinal (GI) diseases is restricted to infectious/viral diseases [7] and inflammatory bowel diseases (IBD) [30]. The seasonal pattern of GI diseases is being debated in the research, with some studies showing peaks on spring and fall [31], summer and fall [32] [33], winter and spring [34] and even others showing no association with seasons [35]. Variation in water quality and pollution, which can differ with seasons, seems to be the external factor most related with GI diseases incidence [36] [37]. Jung et al. instigated, in his article, the fact that the season of birth may play a bigger role in GI diseases incidence than the actual season of disease appearance. Especially when focusing on IBD, he shows that birth during winter is associated with increased risk for IBD later in life [30].

Seasonal patterns of genitourinary and neurological disease incidence are generally neglected and poorly researched. Urinary tract infections (UTI) often have summer peaks of incidence when looking for drug-related sales and Google searches [38], but information about ER admissions, clinic visits or even seasonality of other genitourinary diseases were not found. The scenario is the same for neurological diseases. Most of the research focus on sports seasons [39], work accidents [40], and some specific diseases, such as multiple sclerosis, frequently appearing on spring and summer [41], or Lyme neuroborreliosis, that doesn't show seasons as a reliable predictor [42].

More research is needed to investigate the seasonality of neural and genitourinary diseases. Knowing more about which diseases are related to each season, or even what underlies this relationship can help to improve the predictability and specificity of the public health surveillance systems, and therefore minimize the impact of disease occurrence [3] [4] [43]. Additionally, with seasonal patterns changing as a result of climate change is important to keep track of the newly emerging seasonal patterns of diseases that are being influenced by environmental factors [44] [45]. Considering this, and thinking about the public health relevance of studying seasonal influence, this study aims to assess seasonal patterns of ER admissions for respiratory, cardiovascular, genitourinary, neurological and gastrointestinal diseases community hospital in rural northwestern Pennsylvania.

\section{Methods}

\subsection{Data and Population Characteristics}

The data used for this cross-sectional study came from ER admissions records from the Meadville Medical Center (MMC), between June 2000 and September 2014. This project was approved by the Institutional Review Boards at Allegheny College and the Meadville Medical Center. We analyzed a total of 75,568 ER admissions. For each ER admission we specifically assessed more detailed information, such as the ICD-9 code, sex, insurance, race, age and date, time and year of admission. The MMC is a non-profit community hospital located in 
northwestern Pennsylvania and serves a population composed in its majority of residents from the Crawford County, PA. Crawford County is a rural community located 90 miles north of Pittsburgh, PA and 40 miles south of Erie, PA [46].

\subsection{Variables and Grouping}

The main variables of this study were the diseases categories and seasons. To categorize the groups of diseases we used the ICD-9 code, as following: neurological (Codes 320 - 389.9), cardiovascular (Codes 390 - 459.9), respiratory (Codes 460 - 519.9), gastrointestinal (Codes 520 - 579.9), and genitourinary diseases (Codes 580 629.9) [47]. To determine the seasons we used the following configuration: Spring (March $21^{\text {st }}$ to June $20^{\text {th }}$ ), Summer (June $21^{\text {st }}$ to September $20^{\text {th }}$ ), Fall (September $21^{\text {st }}$ to December $20^{\text {th }}$ ) and Winter (December $21^{\text {st }}$ to March $\left.20^{\text {th }}\right)$.

The data was stratified by sex, insurance type, race and age. Insurance type was divided in three groups: private, governmental or no insurance. Race was also categorized in three groups: Caucasians, African American and Others. Age was not categorized and was only included as a potential confounder in the multivariable analysis.

\subsection{Data Analysis}

The raw data was organized in Excel 2013, and all statistical analysis and tests were performed using SAS 9.4 University version software. If an admission was missing any data, we excluded it from the analyses. We calculated of frequencies of each disease and then completed a bivariate analysis of the data using the Student t-test andchi-square tests. The Cochran-Mantel-Haenszel test was used to determine if sex, insurance, race, or age confounded the relationship between disease and season. The Breslow-Day test was used to check for effect modification. Adjusted odds ratios were calculated using multi-variable logistic regression models. During all the analysis winter was the reference group for seasons, and cardiovascular diseases the reference group for the diseases.

\section{Results}

This study looked at data from a total of 75,568 ER admissions. From those we identified 17,504 (23.16\%) cases of respiratory diseases; 21,320 (28.12\%) cases of gastrointestinal diseases; 8,021 (10.61\%) cases of genitourinary diseases; 17,535 (23.20\%) cases of neurological diseases; and 11,187 (14.80\%) cases of cardiovascular diseases. Our dataset was comprised of a majority of females (9.617; 56\%); Caucasians (16,526; 94\%); individuals with private insurance (10,530; 54\%) (Table 1). The ER admissions were even distributed among the four seasons (Table 1 ).

Through a bivariate analysis of the data, we found no statistically significant relationship between season and gastrointestinal, genitourinary, and neurological disease (Table 2). However, the unadjusted odds ratios (ORs) for respiratory diseases reveal a significant decrease in ER admissions during the spring $(\mathrm{OR}=0.699)$, summer $(\mathrm{OR}=0.553)$, and fall $(\mathrm{OR}=0.833)$ when compared to winter (Table 2$)$.

After adjusting for sex, insurance, rate and age, we found that ER admissions for respiratory diseases were statistically significantly reduced during the spring $(\mathrm{OR}=0.757)$, summer $(\mathrm{OR}=0.579)$, and fall $(\mathrm{OR}=0.741)$, when comparing to the winter season (Table 3). Additionally, we found that there were several differences in ER diagnoses based on insurance type. Individuals with governmental insurance (Medicaid or Medicare) were more likely to be diagnosed with a respiratory disease, but less likely a GI or genitourinary disease than those with no insurance when controlling for season, sex, and race. Similarly, individuals with private insurance were less likely to be diagnosed with a GI or genitourinary disease than those without insurance (Table 3).

\section{Discussion}

\subsection{Overview, Implications and Future Research}

Our analysis of 14 years of ER admissions from the MMC indicates the presence of a seasonal pattern for respiratory diseases, but not for the other four categories of diseases. Our results suggests that respiratory diseases incidence is higher at winter than in all the other seasons, which is consistent with previous research [5]-[7] [48]. 
Table 1. Socio-demographic and admissions information for individuals admitted to the Meadville Medical Center ER for the five pre-established diseases categories (2000-2014).

\begin{tabular}{|c|c|c|c|c|c|c|c|}
\hline \multicolumn{8}{|c|}{ Demographics: Frequency (row \%) } \\
\hline \multicolumn{2}{|c|}{ Variables } & \multirow{2}{*}{$\begin{array}{l}\text { Respiratory } \\
7887 \text { (23.57) }\end{array}$} & \multirow{2}{*}{$\begin{array}{c}\text { Gastrointestinal } \\
10047 \text { (30.02) }\end{array}$} & \multirow{2}{*}{$\begin{array}{c}\text { Genitourinary } \\
2715(8.11)\end{array}$} & \multirow{2}{*}{\begin{tabular}{|l} 
Neurological \\
$7170(21.42)$
\end{tabular}} & Cardiovascular & p-value (chi-square) \\
\hline \multirow{3}{*}{ Sex } & Male & & & & & $5647(16.87)$ & \\
\hline & & & & & & & $<0.0001$ \\
\hline & Female & $9617(22.84)$ & $11273(26.78)$ & $5306(12.50)$ & 10365 (24.62) & $5540(13.16)$ & \\
\hline \multirow{3}{*}{ Insurance } & Private insurance & $10530(25.71)$ & $11048(26.98)$ & $4567(11.15)$ & $12081(29.50)$ & $2730(6.67)$ & \\
\hline & $\begin{array}{l}\text { Government } \\
\text { Insurance }\end{array}$ & 5699 (20.33) & $7535(26.87)$ & $2670(9.52)$ & $4067(14.51)$ & 8067 (28.77) & $<0.0001$ \\
\hline & No insurance & $1275(19.40)$ & $2737(41.64)$ & $784(11.93)$ & $1387(21.10)$ & 390 (5.93) & \\
\hline \multirow{3}{*}{ Race } & African American & $780(22.29)$ & $965(27.57)$ & 377 (10.77) & $841(24.03)$ & $537(15.34)$ & \\
\hline & Others & $171(21.67)$ & $230(29.15)$ & $67(8.49)$ & $191(24.21)$ & $130(16.48)$ & 0.268 \\
\hline & Caucasian & $16526(23.22)$ & 20093 (28.23) & 7566 (10.63) & $16478(23.15)$ & $10504(14.76)$ & \\
\hline \multirow{5}{*}{ Seasons } & Spring & 4244 (21.68) & 5652 (28.88) & $2106(10.76)$ & $4608(23.54)$ & $2964(15.14)$ & \\
\hline & Summer & $3221(17.99)$ & 5324 (29.74) & $2116(11.82)$ & 4393 (24.54) & $2846(15.90)$ & \\
\hline & & & & & & & $<0.0001$ \\
\hline & Fall & 4795 (24.68) & 5403 (27.81) & $2030(10.45)$ & 4388 (22.58) & 2814 (14.48) & \\
\hline & Winter & $5244(28.10)$ & 4941 (26.47) & 1769 (9.48) & $4146(22.22)$ & 2563 (13.73) & \\
\hline
\end{tabular}

The results our study should be used to improve Meadville's public health policies for cold seasons, and more specifically, implement some programs that prepare the ER to receive and treat respiratory cases more efficiently in the cold season. "Winter bed crisis"- a lack of staff and/or material to attend all the population during the cold season-is a common problem in hospitals and ERs [43]. Knowing that respiratory diseases will be more incident during winter, the MMC can prepare the staff and material necessary in advance with the goal of reducing the "winter bed crisis". Additionally, this information can be used to warn the population served by the MMCabout the respiratory health risks that are greater during the winter season. Examples are campaigns to encourage proper nutrition, preparation of appropriate clothing, and arrangement of heating systems, among others.

As mentioned in the Introduction, the combination of climate changes and air pollution is tightly related with the increasing incidence of respiratory diseases [4], and that makes the study of seasonality of these diseases relevant and necessary. What would make research in this area even more relevant to Meadville's public health system would be the possibility of assessing the environmental factors related with the cold season and the incidence of respiratory diseases, at the same time. Some of them end up being intuitive, such as dry air and low temperatures, however others aren't, like air pollution and how climate change is affecting the seasons, and therefore they requires further investigation. Knowing more environmental causes of these diseases would take health policies to another level, improving the city's public health.

In respect to the overall study of seasonal patterns, the field is lacking some global assessment. Studies always highlight the fact that seasonality of diseases change between countries [47], and even hemispheres [3] [20], but more detailed information within this subject is not often researched. As an example, comparison between temperate and tropical places could give us information about which environmental factors are influencing diseases cycles. Also, comparing different countries, that have the same climate configuration, can elucidate some behavioral and cultural practices that could be related to seasonality of diseases. 
Table 2. Unadjusted odds ratio for each of the variables, regards Respiratory Gastrointestinal, Genitourinary and Neurological diseases. Cardiovascular diseases were used as the reference group in the analysis.

\begin{tabular}{|c|c|c|c|c|c|c|}
\hline \multicolumn{7}{|c|}{ Unadjusted ORs (95\%CI) } \\
\hline & Variables & Respiratory & Gastrointestinal & Genitourinary & Neurological & Cardiovascular \\
\hline \multirow{2}{*}{ Sex } & Male & $\begin{array}{c}0.805 \\
(0.7672-0.8437)\end{array}$ & $\begin{array}{c}0.874 \\
(0.8352-0.9153)\end{array}$ & $\begin{array}{c}0.502 \\
(0.4731-0.5326)\end{array}$ & $\begin{array}{c}0.679 \\
(0.6470-0.7118)\end{array}$ & 1.0 (Ref) \\
\hline & Female & 1.0 (Ref) & 1.0 (Ref) & 1.0 (Ref) & 1.0 (Ref) & 1.0 (Ref) \\
\hline \multirow{3}{*}{ Insurance } & Private insurance & $\begin{array}{c}1.180 \\
(1.0454-1.3388)\end{array}$ & $\begin{array}{c}0.577 \\
(0.5145-0.6463)\end{array}$ & $\begin{array}{c}0.832 \\
(0.7305-0.9481)\end{array}$ & $\begin{array}{c}1.244 \\
(1.1039-1.4026)\end{array}$ & 1.0 (Ref) \\
\hline & Government Insurance & $\begin{array}{c}0.216 \\
(0.1920-0.2432)\end{array}$ & $\begin{array}{c}0.133 \\
(0.1192-0.1487)\end{array}$ & $\begin{array}{c}0.165 \\
(0.1447-0.1873)\end{array}$ & $\begin{array}{c}0.142 \\
(0.1259-0.1596)\end{array}$ & 1.0 (Ref) \\
\hline & No insurance & 1.0 (Ref) & 1.0 (Ref) & 1.0 (Ref) & 1.0 (Ref) & 1.0 (Ref) \\
\hline \multirow{3}{*}{ Race } & African American & $\begin{array}{c}0.923 \\
(0.8249-1.0332)\end{array}$ & $\begin{array}{c}0.939 \\
(0.8431-1.0467)\end{array}$ & $\begin{array}{c}0.975 \\
(0.8516-1.1155)\end{array}$ & $\begin{array}{c}0.998 \\
(0.8934-1.1155)\end{array}$ & 1.0 (Ref) \\
\hline & Others & $\begin{array}{c}0.836 \\
(0.6647-1.0516)\end{array}$ & $\begin{array}{c}0.925 \\
(0.7450-1.1483)\end{array}$ & $\begin{array}{c}0.716 \\
(0.5321-0.9622)\end{array}$ & $\begin{array}{c}0.937 \\
(0.7485-1.1719)\end{array}$ & 1.0 (Ref) \\
\hline & Caucasian & 1.0 (Ref) & 1.0 (Ref) & 1.0 (Ref) & 1.0 (Ref) & 1.0 (Ref) \\
\hline \multirow{4}{*}{ Seasons } & Spring & $\begin{array}{c}0.699 \\
(0.6547-0.7480)\end{array}$ & $\begin{array}{c}0.989 \\
(0.9267-1.0558)\end{array}$ & $\begin{array}{c}1.029 \\
(0.9480-1.1179)\end{array}$ & $\begin{array}{c}0.961 \\
(0.8983-1.0282)\end{array}$ & 1.0 (Ref) \\
\hline & Summer & $\begin{array}{c}0.553 \\
(0.5162-0.5927)\end{array}$ & $\begin{array}{c}0.970 \\
(0.9085-1.0365)\end{array}$ & $\begin{array}{c}1.077 \\
(0.9917-1.1701)\end{array}$ & $\begin{array}{c}0.954 \\
(0.8913-1.0215)\end{array}$ & 1.0 (Ref) \\
\hline & Fall & $\begin{array}{c}0.833 \\
(0.7794-0.8899)\end{array}$ & $\begin{array}{c}0.996 \\
(0.9324-1.0639)\end{array}$ & $\begin{array}{c}1.045 \\
(0.9617-1.1359)\end{array}$ & $\begin{array}{c}0.964 \\
(0.9003-1.0321)\end{array}$ & 1.0 (Ref) \\
\hline & Winter & 1.0 (Ref) & 1.0 (Ref) & 1.0 (Ref) & 1.0 (Ref) & 1.0 (Ref) \\
\hline Age $^{*}$ & Mean (sd) & $46.0(28.6)$ & $49.6(23.9)$ & $55.9(23.0)$ & $43.1(27.5)$ & (Ref) \\
\hline
\end{tabular}

\subsection{Strengths and Limitations}

One strength of our study is that we assessed approximately 14 years of ER admission data, summing a total of 75,568 cases. Also, from each of these admissions we had access to a broad range of information such as ICD-9 code, cause of admission, date, time and year of admission, sex, race, and insurance. Our data allowed us to look at both potential confounders to the disease-season relationship as well as trends over time. We feel the reliability of our data will allow our results to be used to help improve the public health system of Meadville, and it can even be generalized to inspire future research of seasonality in other small cities around the United States.

The cross-sectional collection and analysis of data does not allow us to assume causality from our results. We therefore, can only discuss our results in terms of associations between season and disease. Additionally, for our study, seasons were not assessed using any environmental factors, such as temperature, humidity, rain fall or pollen counts. Even though the categorization of seasons followed precisely the standard annual cycle, this division alone does not account for possible interference of seasonal variations or climate change. Basically, without using environmental factors, we cannot certainly assess if the winter in one year was more or less rigorous than in others, and how this could potentially influence the seasonality of respiratory diseases.

\section{Conclusion}

Research in the field of seasonality of diseases is still considerable inconsistent. While some diseases categories have a seasonal pattern while established, like cardiovascular diseases and winter, others still show a lot of variation (gastrointestinal, genitourinary, neurological). In our study we looked at seasonality of ER admissions 
Table 3. Adjusted odds ratio for each of the variables, regards Respiratory Gastrointestinal, Genitourinary and Neurological diseases. ORs were obtained after performing a multivariable analysis using regression model.

\begin{tabular}{|c|c|c|c|c|c|c|}
\hline \multicolumn{7}{|c|}{ Adjusted ORs (95\%CI) } \\
\hline & Variables & Respiratory & Gastrointestinal & Genitourinary & Neurological & Cardiovascular \\
\hline \multirow{2}{*}{ Sex } & Male & $\begin{array}{c}0.643 \\
(0.606-0.683)\end{array}$ & $\begin{array}{c}0.705 \\
(0.667-0.744)\end{array}$ & $\begin{array}{c}0.608 \\
(0.567-0.653)\end{array}$ & $\begin{array}{c}0.456 \\
(0.425-0.488)\end{array}$ & 1.0 (Ref) \\
\hline & Female & 1.0 (Ref) & 1.0 (Ref) & 1.0 (Ref) & 1.0 (Ref) & 1.0 (Ref) \\
\hline \multirow{3}{*}{ Insurance } & Private insurance & $\begin{array}{c}0.936 \\
(0.812-1.078)\end{array}$ & $\begin{array}{c}0.590 \\
(0.521-0.668)\end{array}$ & $\begin{array}{c}0.851 \\
(0.734-0.988)\end{array}$ & $\begin{array}{c}0.999 \\
(0.863-1.157)\end{array}$ & 1.0 (Ref) \\
\hline & $\begin{array}{l}\text { Government } \\
\text { Insurance }\end{array}$ & $\begin{array}{c}1.375 \\
(1.186-1.594)\end{array}$ & $\begin{array}{c}0.666 \\
(0.585-0.758)\end{array}$ & $\begin{array}{c}0.828 \\
(0.706-0.970)\end{array}$ & $\begin{array}{c}1.042 \\
(0.893-1.215)\end{array}$ & 1.0 (Ref) \\
\hline & No insurance & 1.0 (Ref) & 1.0 (Ref) & 1.0 (Ref) & 1.0 (Ref) & 1.0 (Ref) \\
\hline \multirow{3}{*}{ Race } & African American & $\begin{array}{c}0.914 \\
(0.794-1.052)\end{array}$ & $\begin{array}{c}0.968 \\
(0.852-1.101)\end{array}$ & $\begin{array}{c}0.936 \\
(0.794-1.104)\end{array}$ & $\begin{array}{c}1.048 \\
(0.894-1.229)\end{array}$ & 1.0 (Ref) \\
\hline & Others & $\begin{array}{c}0.637 \\
(0.474-0.855)\end{array}$ & $\begin{array}{c}0.851 \\
(0.660-1.098)\end{array}$ & $\begin{array}{c}0.675 \\
(0.475-0.961)\end{array}$ & $\begin{array}{c}0.869 \\
(0.633-1.194)\end{array}$ & 1.0 (Ref) \\
\hline & Caucasian & 1.0 (Ref) & 1.0 (Ref) & 1.0 (Ref) & 1.0 (Ref) & 1.0 (Ref) \\
\hline \multirow{4}{*}{ Seasons } & Spring & $\begin{array}{c}0.757 \\
(0.697-0.822)\end{array}$ & $\begin{array}{c}1.001 \\
(0.927-1.082)\end{array}$ & $\begin{array}{c}1.004 \\
(0.908-1.110)\end{array}$ & $\begin{array}{c}1.073 \\
(0.972-1.184)\end{array}$ & 1.0 (Ref) \\
\hline & Summer & $\begin{array}{c}0.579 \\
(0.531-0.632)\end{array}$ & $\begin{array}{c}0.929 \\
(0.858-1.005)\end{array}$ & $\begin{array}{c}0.972 \\
(0.878-1.075)\end{array}$ & $\begin{array}{c}1.015 \\
(0.919-1.120)\end{array}$ & 1.0 (Ref) \\
\hline & Fall & $\begin{array}{c}0.741 \\
(0.681-0.806)\end{array}$ & $\begin{array}{c}0.938 \\
(0.867-1.015)\end{array}$ & $\begin{array}{c}0.943 \\
(0.851-1.044)\end{array}$ & $\begin{array}{c}0.962 \\
(0.870-1.063)\end{array}$ & 1.0 (Ref) \\
\hline & Winter & 1.0 (Ref) & 1.0 (Ref) & 1.0 (Ref) & 1.0 (Ref) & 1.0 (Ref) \\
\hline
\end{tabular}

using 14 years of data from the MMC in northwestern PA. We did not find any significant difference in seasonality of ER admissions for gastrointestinal, genitourinary and neurological diseases, when comparing at CVD. However, we found significantly fewer ER admissions for respiratory diseases in the spring, summer, and fall, when comparing to the winter across 14 years of data.

The application of our results would mainly be related to improve Meadville's public health policies for cold seasons, and more specifically, implement some programs that prepare the ER to receive and treat respiratory cases more efficiently during the cold season. However, the methodology we developed and used to assess the seasonality of diseases can be used by other small community hospitals to identify patterns of ER admissions by season. In future research, we propose an investigation of environmental factors related to respiratory diseases in Meadville during the winter. Information from this study could be used to further improve local health policies.

\section{References}

[1] Dowell, S.F. (2001) Seasonal Variation in Host Susceptibility and Cycles of Certain Infectious Diseases. Emergency Infectious Diseases, 7, 369-374. http://dx.doi.org/10.3201/eid0703.017301

[2] Grassly, N.C. and Fraser, C. (2006) Seasonal Infectious Disease Epidemiology. ProcBiolSci, 273, 2541-2550. http://dx.doi.org/10.1098/rspb.2006.3604

[3] Fisman, D.N. (2007) Seasonality of Infectious Diseases. Annual Review of Public Health, 28, 127-143. http://dx.doi.org/10.1146/annurev.publhealth.28.021406.144128

[4] Desalu, O.O. (2011) Seasonal Variation in Hospitalisation for Respiratory Diseases in the Tropical Rain Forest of South Western Nigeria. The Nigerian Postgraduate Medical Journal, 18, 39-43.

[5] Douglas, A.S., Rawles, J.M., Alexander, E. and Allan, T.M. (1991) Winter Pressure on Hospital Beds. British Medical 
Journal, 303, 508-509. http://dx.doi.org/10.1136/bmj.303.6801.508-a

[6] Schrijver, T.V., Brand, P.L.P. and Bekhof, J. (2016) Seasonal Variation of Diseases in Children: A 6-Year Prospective Cohort Study in a General Hospital. European Journal of Pediatrics, 175, 457-464. http://dx.doi.org/10.1007/s00431-015-2653-y

[7] Yang, T.O., Huang, W., Chen, M. and Chen, P. (2014) Seasonal Synchrony in Incidences of Commons Infectious Diagnoses in Early Childhood among Neighbouring Regions. International Journal of Infectious Diseases, 28, 214-216. http://dx.doi.org/10.1016/j.ijid.2014.06.015

[8] Andersen, I.B., Lundqvist, G.R. and Proctor, D.F. (1972) Human Nasal Mucosal Function under Four Controlled Humidities. The American Review of Respiratory Diseases, 106, 438-449. http://dx.doi.org/10.1164/arrd.1972.106.3.438

[9] Baetjer, A.M. (1968) Role of Environmental Temperature and Humidity in Susceptibility to Disease. Archives of Environmental Health, 16, 565-570. http://dx.doi.org/10.1080/00039896.1968.10665104

[10] Agius, A.M., Smallman, L.A. and Pahor, A.L. (1998) Age, Smoking, and Nasal Ciliary Beat Frequency. Clinical Otolaryngology, 23, 227-230. http://dx.doi.org/10.1046/j.1365-2273.1998.00141.x

[11] Grose, E.C., et al. (1982) Pulmonary Host Defense Responses to Inhalation of Sulfuric Acid and Ozone. Journal of Toxicology and Environmental Health, 10, 351-362. http://dx.doi.org/10.1080/15287398209530258

[12] Verra, F., Escudier, E., Lebargy, F., Bernaudin, J.F., De Cremoux, H. and Bignon, J. (1995) Ciliary Abnormalities in Bronchial Epithelium of Smokers, Ex-Smokers, and Nonsmokers. American Journal of Respiratory and Critical Care Medicine, 151, 630-634. http://dx.doi.org/10.1164/ajrccm/151.3 Pt 1.630

[13] Ross, A., Collins, M. and Sanders, C. (1990) Upper Respiratory Tract Infection in Children, Domestic Temperatures, and Humidity. Journal of Epidemiology and Community Health, 44, 142-146. http://dx.doi.org/10.1136/jech.44.2.142

[14] Spengler, J.D., Jaakkola, J.J., Parise, H., Katsnelson, B.A., Privalova, L.I. and Kosheleva, A.A. (2004) Housing Characteristics and Children's Respiratory Health in the RUSSIAN federation. American Journal of Public Health, 94, 657-662. http://dx.doi.org/10.2105/AJPH.94.4.657

[15] Douglas, A.S., Strachan, D.P. and Maxwell, J.D. (1996) Seasonality of Tuberculosis: The Reverse of Other Respiratory Diseases in the UK. Thorax, 51, 944-946. http://dx.doi.org/10.1136/thx.51.9.944

[16] Ornato, J.P., Peberdy, M.A., Chandra, N.C. and Bush, D.E. (1996) Seasonal Pattern of Acute Myocardial Infarction in the National Registry of Myocardial Infarction. Journal of the American College of Cardiology, 28, 1684-1688. http://dx.doi.org/10.1016/S0735-1097(96)00411-1

[17] Arntz, H.R., Willich, S.N., Schreiber, C., Bruggemann, T., Stern, R. and Schultheiss, H.P. (2000) Diurnal, Weekly and Seasonal Variation of Sudden Death: Population-Based Analysis of 24,061 Consecutive Cases. European Health Journal, 21, 315-320. http://dx.doi.org/10.1053/euhj.1999.1739

[18] Boulay, F., Berthier, F., Sisteron, O., Gendreike, Y. and Gibelin, P. (1999) Seasonal Variation in Chronic Heart Failure Hospitalizations and Mortality in France. Circulation, 100, 280-286. http://dx.doi.org/10.1161/01.CIR.100.3.280

[19] Mehta, R.H., et al. (2002) Chronobiological Patterns of Acute Aortic Dissection. Circulation, 106, 1110-1115. http://dx.doi.org/10.1161/01.CIR.0000027568.39540.4B

[20] Comelli, I., Ferro, J., Lippi, G., Comelli, D., Sartori, E. and Cervellin, G. (2014) Incidence of Acute-Onset Atrial Fibrillation Correlates with Air Temperature-Results of a Nine-Year Survey. Journal of Epidemiology and Global Health, 4, 151-157. http://dx.doi.org/10.1016/j.jegh.2013.12.003

[21] Khan, R.C. and Halder, D. (2014) Effect of Seasonal Variation on Hospital Admission Due to Cardiovascular Diseases-Findings from an Observational Study in a Divisional Hospital in Bangladesh. BMC Cardiovascular Disorders, 14, 76-82. http://dx.doi.org/10.1186/1471-2261-14-76

[22] Mamun, M.A., Rumana, N., Kita, Y. and Turin, T.C. (2014) Combining the Effects of Conventional Risk Factors and Environmental Triggering Factors While Studying Seasonality in Acute Myocardial Infarction. Environmental Pollution, 189, 252-253. http://dx.doi.org/10.1016/j.envpol.2014.03.012

[23] Abrignani, M.G., et al. (2009) Influence of Climatic Variables on Acute Myocardial Infarction Hospital Admissions. International Journal of Cardiology, 137, 123-129. http://dx.doi.org/10.1016/j.ijcard.2008.06.036

[24] Kuma, N., Venkatraman, A. and Garg, N. (2015) Seasonality in Acute Ischemic Stroke Related Hospitalizations and Case Fatality Rate in the United States. International Journal of Cardiology, 195, 134-135. http://dx.doi.org/10.1016/j.ijcard.2015.05.122

[25] Reavey, M., Saner, H., Paccaud, F. and Marques-Vidal, P. (2013) Exploring the Periodicity of Cardiovascular Events in Switzerland: Variations in Deaths and Hospitalizations across Seasons, Day of the Week, and Hour of the Day. International Journal of Cardiology, 168, 2195-2200. http://dx.doi.org/10.1016/j.ijcard.2013.01.224

[26] Qui, H., et al. (2013) Is Greater Temperature Change within a Day Associated with Increased Emergency Hospital Admissions for Heart Failure? Circulation: Heart Failure, 6, 930-935. 
http://dx.doi.org/10.1161/CIRCHEARTFAILURE.113.000360

[27] Brennan, P.J., Greenberg, G., Miall, W.E. and Thompson, S.G. (1982) Seasonal Variation in Arterial Blood Pressure. British Medical Journal, 285, 919-923. http://dx.doi.org/10.1136/bmj.285.6346.919

[28] Modest, P.A. (2013) Seasonal Blood Pressure Changes: An Independent Relationship with Temperature and Daylight Hours. Hypertension, 61, 908-914. http://dx.doi.org/10.1161/HYPERTENSIONAHA.111.00315

[29] Marti-Soler, H., et al. (2014) Seasonality of Cardiovascular Risk Factors: An Analysis Including over 230000 Participants in 15 Countries. Heart, 100, 1517-1523. http://dx.doi.org/10.1136/heartjnl-2014-305623

[30] Jung, Y.S., et al. (2013) Seasonal Variation in Months of Birth and Symptom Flares in Korean Patients with Inflammatory Bowel Disease. Gut and Liver, 7, 661-667. http://dx.doi.org/10.5009/gnl.2013.7.6.661

[31] Lee, J.H., Cheon, J.H., Hong, S.P., Kim, T.I. and Kim, W.H. (2015) Seasonal Variation in Flares of Intestinal Behçet’s Disease. Digestive Diseases and Science, 60, 3373-3378. http://dx.doi.org/10.1007/s10620-015-3863-x

[32] Ilves, I., Fagerström, A., Herzig, K.-H., Juvonen, P., Miettinen, P. and Paajanen, H. (2014) Seasonal Variations of Acute Appendicitis and Nonspecific Abdominal Pain in Finland. World Journal of Gastroenterology, 20, 4037-4042. http://dx.doi.org/10.3748/wjg.v20.i14.4037

[33] Harper, S.L., Edge, V.L., Schuster-Wallace, C.J., Berke, O. and McEwen, S.A. (2011) Weather, Water Quality and Infectious Gastrointestinal Illness in Two Inuit Communities in Nunatsiavut, Canada: Potential Implications for Climate Change. EcoHealth, 8, 93-108. http://dx.doi.org/10.1007/s10393-011-0690-1

[34] Koido, S., et al. (2013) Seasonal Variations in the Onset of Ulcerative Colitis in Japan. World Journal of Gastroenterology, 19, 9063-9068. http://dx.doi.org/10.3748/wjg.v19.i47.9063

[35] Raboni, S.M., et al. (2014) Acute Gastroenteritis and Enteric Viruses in Hospitalised Children in Southern Brazil: Aetiology, Seasonality and Clinical Outcomes. Memórias do Instituto Oswaldo Cruz, 109, 428-435. http://dx.doi.org/10.1590/0074-0276140066

[36] Kulinkina, A.V., et al. (2016) Seasonality of Water Quality and Diarrheal Diseases Counts in Urban and Rural Settings in South India. Nature, 6, Article No. 20521. http://dx.doi.org/10.1038/srep20521

[37] Jagai, J.S., Griffiths, J.K., Kirshen, P.K., Webb, P. and Naumova, E.N. (2012) Seasonal Patterns of Gastrointestinal Illness and Streamflow along the Ohio River. International Journal of Environmental Research and Public Health, 9, 1771-1790. http://dx.doi.org/10.3390/ijerph9051771

[38] Rossignol, L., Pelat, C., Lambert, B., Flahault, A., Chartier-Kastler, E. and Hanslik, T. (2013) A Method to Assess Seasonality of Urinary Tract Infections Based on Medication Sales and Google Trends. PLOS ONE, 8, e76020. http://dx.doi.org/10.1371/journal.pone.0076020

[39] Gardner, A., et al. (2014) A Systematic Review of Concussion in Rugby League. British Journal of Sports Medicine, 49, 495-498. http://dx.doi.org/10.1136/bjsports-2013-093102

[40] Kica, J. and Rosenman, K.D. (2014) Surveillance for Work-Related Skull Fractures in Michigan. Journal of Safety Research, 51, 49-56. http://dx.doi.org/10.1016/j.jsr.2014.09.003

[41] Muto, M., Mori, M., Sato, Y., Uzawa, A., Masuda, S. and Kuwabara, S. (2012) Seasonality of Multiple Sclerosis and Neuromyelitis Optica Exacerbations in Japan. Multiple Sclerosis Journal, 19, 378-379. http://dx.doi.org/10.1177/1352458512452332

[42] Petersen, B.B., Moller, J.K. and Vilholm, O.J. (2015) Season Is an Unreliable Predictor of Lyme Neuroborreliosis. Danish Medical Journal, 62, A5084.

[43] D’Souza, R.M., et al. (2007) Seasonal Variation in Acute Hospital Admissions and Emergency Room Presentations among Children in the Australian Capital Territory. Journal of Paediatrics and Child Health, 43, 359-365. http://dx.doi.org/10.1111/j.1440-1754.2007.01080.x

[44] Harvell, C.D., et al. (2002) Climate Warming and Disease Risks for Terrestrial and Marine Biota. Science, 296, 21582162. http://dx.doi.org/10.1126/science.1063699

[45] Kuhn, K., Campbell-Lendrum, D., Haines, A. and Cox, J. (2005) Using Climate to Predict Infectious Disease Epidemics. World Health Organ, Geneva.

[46] Zaborowski, M. and Dawson, R. (2016) Emergency Department Admissions for Dental \& Oral Health Concerns in Rural Northwestern Pennsylvania. Open Journal of Emergency Medicine, 4, $23-32$. http://dx.doi.org/10.4236/ojem.2016.41004

[47] AAPC (2016) ICD-9-CM Code Set. https://www.aapc.com/resources/medical-coding/icd9.aspx

[48] Zhang, Y., et al. (2015) Burden of Respiratory Syncytial Virus Infections in China: Systematic Review and MetaAnalysis. Journal of Global Health, 5, 020417. 


\section{Submit or recommend next manuscript to SCIRP and we will provide best service for you:}

Accepting pre-submission inquiries through Email, Facebook, Linkedin, Twitter, etc A wide selection of journals (inclusive of 9 subjects, more than 200 journals)

Providing a 24-hour high-quality service

User-friendly online submission system

Fair and swift peer-review system

Efficient typesetting and proofreading procedure

Display of the result of downloads and visits, as well as the number of cited articles

Maximum dissemination of your research work

Submit your manuscript at: http://papersubmission.scirp.org/ 